\title{
Olfactory response of predatory mites to vegetative and reproductive parts of coconut palm infested by Aceria guerreronis
}

\author{
José Wagner S. Melo • Debora B. Lima • Angelo Pallini • \\ José Eudes M. Oliveira • Manoel G. C. Gondim Jr.
}

Received: 26 November 2010/ Accepted: 2 April 2011

(C) Springer Science+Business Media B.V. 2011

\begin{abstract}
The phytophagous mite Aceria guerreronis Keifer is an important pest of coconut worldwide. A promising method of control for this pest is the use of predatory mites. Neoseiulus baraki (Athias-Henriot) and Proctolaelaps bickleyi Bram are predatory mites found in association with A. guerreronis in the field. To understand how these predators respond to olfactory cues from A. guerreronis and its host plant, the foraging behavior of the predatory mites was investigated in a Y-tube olfactometer and on T-shaped arenas. The predators were subjected to choose in an olfactometer: (1) isolated parts (leaflet, spikelet or fruit) of infested coconut plant or clean air stream; (2) isolated parts of non-infested or infested coconut plant; and (3) two different plant parts previously shown to be attractive. Using T-shaped arenas the predators were offered all possible binary combinations of discs of coconut fruit epidermis infested with A. guerreronis, non-infested discs or coconut pollen. The results showed that both predators were preferred (the volatile cues from) the infested plant parts over clean air. When subjected to odours from different infested or non-infested plant parts, predators preferred the infested parts. Among the infested plant parts, the spikelets induced the greatest attraction to predators. On the arenas, both predators preferred discs of coconut fruits infested with A. guerreronis over every other alternative. The results show that both predators are able to locate A. guerreronis by olfactory stimuli. Foraging strategies and implications for biological control are discussed.
\end{abstract}

Keywords Cocos nucifera $\cdot$ Aceria guerreronis $\cdot$ Predators $\cdot$ Volatile $\cdot$ Behavior

J. W. S. Melo ( () ) D. B. Lima · M. G. C. Gondim Jr.

Depto. Agronomia, Área de Fitossanidade, Universidade Federal Rural de Pernambuco,

Recife,

PE 52171-900, Brazil

e-mail: wagnermelo@hotmail.com

A. Pallini

Depto. Biologia Animal/Entomologia, Universidade Federal de Viçosa, Viçosa, MG 36570-000, Brazil

J. E. M. Oliveira

Entomologia, Embrapa Semiárido, Petrolina, PE 56302-970, Brazil 


\section{Introduction}

Aceria guerreronis Keifer (Acari: Eriophyidae) is a major pest of cocconut (Moore and Howard 1996; Haq et al. 2002). The mite lives on the fruit, beneath the perianth, feeding on the meristematic tissue, which leads to surface scars, reduces fruit growth and causes premature fruit fall (Doreste 1968; Moore and Howard 1996; Lawson-Balagbo et al. 2007b). It is widespread in most coconut growing regions of the Americas and Africa and has been established rapidly in some major coconut producing countries in Asia (Fernando et al. 2002; Haq et al. 2002; Ramaraju et al. 2002; Navia et al. 2006).

The use of acaricides, so far the most effective method for control of A. guerreronis, is an expensive practice that requires periodical applications and the purchase of equipment and supplies (Moore and Howard 1996; Ramaraju et al. 2002). Thus, given the high costs, the use of acaricides can be economically prohibitive for small-scale farmers (Persley 1992; Moore and Howard 1996). In such systems of production, biological control becomes an economically viable option for small producers of coconut, especially for those who grow varieties of tall trees, which increases the costs and complexity of the acaricide applications (Moore and Howard 1996; Ramaraju et al. 2002). Currently, the search for predators of A. guerreronis, aiming to use them in biological control, has been quite intense (Kumar and Singh 2000; Lawson-Balagbo et al. 2007a, b, 2008a, b; Domingos et al. 2010; Fernando et al. 2010).

Among the predatory mites found in association with A. guerreronis, species belonging to the families Phytoseiidae and Ascidae seem to be the most promising natural enemies (de Moraes and Zacarias 2002; Lawson-Balagbo et al. 2007a; Reis et al. 2008; Domingos et al. 2010; Fernando et al. 2010). Neoseiulus baraki (Athias-Henriot), N. paspalivorus (De Leon) (Phytoseiidae), Proctolaelaps bickleyi Bram and P. bulbosus Moraes, Reis and Gondim Jr. (Ascidae) are the most frequently found predators of A. guerreronis on coconut fruits (Lawson-Balagbo et al. 2008a; Reis et al. 2008). Laboratory studies have indicated that the coconut mite is a suitable prey to those predators (Lawson-Balagbo et al. 2008b; Domingos et al. 2010). However, a good performance of the predator under laboratory conditions might not be reproduced in the field if, for example, the foraging ability of this predator is not adequate (Sabelis and Janssen 1993; Janssen et al. 1997; Oliveira et al. 2009).

Understanding the foraging behavior of natural enemies in real agroecosystems is necessary to increase the effectiveness of biological control programs. It is known that indirect effects within a food web can mediate interactions between organisms (Price et al. 1980; Sabelis et al. 1998; Van Zandt and Agrawal 2004; Arimura et al. 2005). Plants attacked by mites produce volatiles that signal the presence of these herbivores to predatory mites (Dicke and Sabelis 1988; Dicke 1994; Dicke et al. 1998, 2003; Janssen et al. 1999; Maeda et al. 2000; Maeda and Tabayashi 2001; Sabelis et al. 2001; Arimura et al. 2005). Phytoseiid predators use chemoreceptors present on the palps and tarsi of the forelegs to capture these chemical cues from the plants to search for their prey (Jagers op Akkerhuis et al. 1985). The absence of eyes turns these predators dependent on chemical and/or tactile stimuli to facilitate the encountering with the prey. Reports regarding the perception of odours by predatory mites of the family Ascidae have not been found in the literature. However, given its phylogenetic proximity with the family Phytoseiidae, it is assumed that these predators also have structures to detect the plant chemical cues.

Foraging directly interferes with the efficiency of a particular biological control agent. In this study, we evaluated the ability of $N$. baraki and $P$. bickleyi to identify and differentiate odours from parts of coconut plants infested or not by A. guerreronis. 


\section{Materials and methods}

Collection, establishment and rearing of predatory mites

Stock colonies of $N$. baraki and P. bickleyi were established with approximately 100 individuals of each species collected in fruits of Cocos nucifera L. from Itamaracá-PE $\left(07^{\circ} 46^{\prime} \mathrm{S}, 34^{\circ} 52^{\prime} \mathrm{W}\right)$. Each rearing unit consisted of a black PVC disc $(13 \mathrm{~cm}$ in diameter, $1 \mathrm{~mm}$ thick) laid onto a disc of foam mat placed in a plastic tray. The margin of the PVC disc was covered with a band of hydrophilic cotton, and both the foam mat and the cotton band were kept wet by daily addition of distilled water into the tray. Colonies of $N$. baraki and $P$. bickleyi were reared on A. guerreronis offered in small pieces of infested meristematic tissue of coconut fruits that were previously inspected to prevent contamination of the colony and replaced every third day. The units were maintained in laboratory at $27.5 \pm 0.5^{\circ} \mathrm{C}, 70 \pm 10 \% \mathrm{RH}$ and $12: 12 \mathrm{LD}$ photoperiod.

\section{Olfactometer experiments}

The response of $N$. baraki and P. bickleyi to odour sources was determined in a two-choice test, using a Y-tube olfactometer (Sabelis and van de Baan 1983; Janssen et al. 1999). The olfactometer consisted of a Y-shaped glass tube $(27 \mathrm{~cm}$ long $\times 3.5 \mathrm{~cm}$ inner diameter $)$ with a Y-shaped metal wire fixed in the middle of the glass tube to channel the mites (Sabelis and van de Baan 1983). The base of the tube was connected to an air pump that produced an airflow from the arms of the tube to the base. Airflow through both arms of the Y-tube was calibrated with a digital flow meter with needle valves between the air outlet of the containers of the odour sources and the arms of the olfactometer. When wind speeds in both arms are equal, the odours form two neatly separated fields in the base of the Y-tube with the interface coinciding with the metal wire. Acrylic boxes $(50 \mathrm{~cm} \times 36 \mathrm{~cm} \times 43 \mathrm{~cm})$ containing the odour sources were connected by a transparent hose to the end of each of the two arms. The boxes were used for the following odour sources: (1) clean air; (2) isolated parts (leaflet, spikelet or fruit) of non-infested coconut plants; and (3) isolated parts of infested coconut plants. When the system was on, an airflow coming from the boxes passed through the tube-the predatory mite to be tested was introduced in the base of the tube, walked upwind along the wire inside the tube, making a decision for one of the two odour sources at the ' $\mathrm{Y}$ ' junction. The air speed inside the glass tube was $0.5 \mathrm{~m} / \mathrm{s}$ in each arm, measured through digital anemometers and calibrated by manual registers. Predators were starved for $4 \mathrm{~h}$ prior to the experiments.

For the odour source, infested and non-infested plants were used. To characterize the plant infestation, all fruits were visually inspected in the field to check for damage. To check for the presence of mites, $10 \%$ of the fruits of each bunch of a plant was sampled. These fruits were taken to the laboratory and examined under the stereomicroscope. Plants that showed no damaged fruits and no mites were considered as non-infested. Infested plants had both, damaged fruits and mites. Plant that showed any sign of damage or disease caused by other arthropods were discarded as well as plants in which arthropods other than A. guerreronis were found during lab inspection. Each of the odour sources consisted of parts (60 leaflets, 20 spikelets or 10 fruits) of infested and non-infested coconut plants. The leaflets were collected from leaf 10 (assigning 0 for the top most spear leaf which is just opened and counting the leaves downwards, according to Passos 1994), the spikelets (inflorescence with male and female flowers) were collected before fecundation, and the fruits were 3 months old (with 16-32\% damage, according to Galvão et al. 2008) when 
collected from the bunches. Assuming this procedure we standardized the age of the leaflets and spikelets used in the experiments. The plant parts were collected in coconut fields (cv. Dwarf Green) in the vicinity of Recife, Brazil. They were placed in a plastic bag, which was then placed into a styrofoam box and brought to the laboratory where they were kept for 2 days at $20^{\circ} \mathrm{C}$ and $70 \% \mathrm{RH}$ until use in the experiments.

Three olfactometer experiments were carried out at $24-27^{\circ} \mathrm{C}$ and $60-80 \% \mathrm{RH}$. The choices of odour sources in each experiment were: (1) isolated parts (leaflets, spikelets or fruits) of coconut plant infested by A. guerreronis versus plant odour-free air; (2) isolated parts of non-infested coconut plant versus isolated parts of infested coconut plant; and (3) different parts earlier detected as more attractive. Additional comparisons were done for $P$. bickelyi using 10 infested aborted fruits and 10 infested non-aborted fruits. These comparisons were done given the larger impact of $P$. bickelyi on infested aborted fruits in field conditions. Each experiment was replicated three times, using different sets of plant parts and mites. Females were observed for a maximum of $5 \mathrm{~min}$. When the end of an arm was not reached within the $5 \mathrm{~min}$, it was considered that no choice was made. The percentage of predators that did not make a choice in each replicate was very low (1-2\%), and these predators were not included in the analysis. Each replicate experiment was continued until 20 females had responded to any odour source. After five tested mites, the position of the odour source was switched to avoid uncontrollable asymmetries in the experimental set-up. In each replicate, we changed the odour sources (air and parts infested or not by the coconut mite) to avoid pseudoreplication (Hurlbert 1984).

Differences on number of $N$. baraki and $P$. bickleyi females choosing the odour sources were tested using a G-test with expected fractions of 0.5 for each odour source. Pooled results were tested with a replicated goodness-of-fit test (Sokal and Rohlf 1995).

\section{Arenas}

T-shaped arenas were used to evaluate how the predators $N$. baraki and P. bickleyi locate their prey (A. guerreronis) on coconut plants. The experimental arena consisted of a T-shaped runway cut from black PVC disc (Fig. 1). Each arena was placed on a foam mat in a plastic tray $(210 \mathrm{~mm} \times 150 \mathrm{~mm} \times 40 \mathrm{~mm})$. The borders of the T-shaped arena were covered with a band of cotton wool that touched the foam mat. The mat and the cotton

Fig. 1 Experimental 'T-arena'

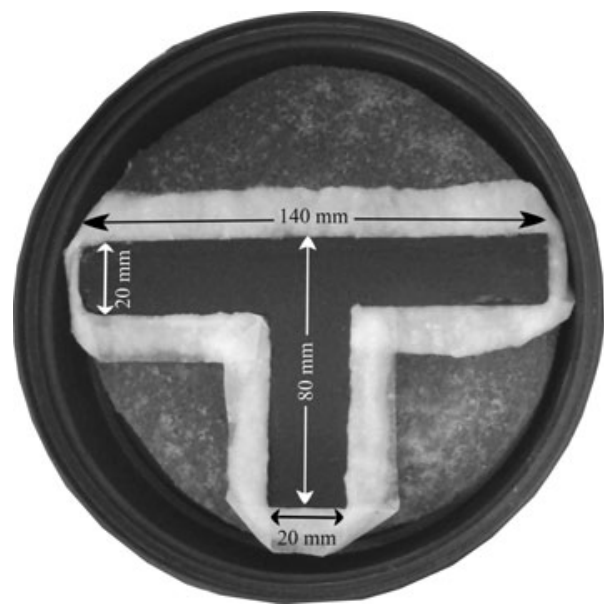


wool were kept moist by adding distilled water to the tray. To verify the suitability and non-directionality of the experimental set-up, a blank test was initially performed. In this test, two discs of the epidermis of a coconut fruit infested with A. guerreronis $(7 \mathrm{~mm}$ diameter) containing about 360 active stages of A. guerreronis were placed at the end of each arm of the ' $T$ ' (left and right). Subsequently, for each predator, 80 females (20 females per replicate) were transferred from the stock colony onto the bottom arm (without food) of the T-shaped arena. After 15 and $30 \mathrm{~min}, 1,2,4,8$ and $24 \mathrm{~h}$, the number of predators on each arm was evaluated. Upon verification of the suitability of the experimental set up, the predators were offered to choose between odour sources (discs of epidermis of coconut fruits infested with A. guerreronis, non-infested discs or coconut pollen). They were paired tested on all combinations. For N. baraki, we also evaluated the effect of light on the predator's choice. For this, the choice experiment between epidermis disc of coconut fruits infested by A. guerreronis and coconut pollen was replicated in the absence of light. The measurements were made at intervals of 15, $30 \mathrm{~min}, 1,2,4$ and $8 \mathrm{~h}$. The methodology of evaluation was similar to the previous tests. All comparisons were replicated four times. The proportions of each predators on each arm at different periods were compared for each test by a $\chi^{2}$ test $(\alpha=0.05)$ using SAS version 8.02 (SAS Institute 1999).

\section{Results}

Olfactometer experiments

Both, $N$. baraki and P. bickleyi, preferred isolated parts of infested coconut plant over clean air (Fig. 2). There were no significant differences among replicates $\left(\mathrm{G}_{\mathrm{H}}<3.99\right.$, d.f. $=3$, $P>0.26)$.

When given a choice between odours from various infested versus non-infested plant parts, both predators preferred the infested parts. Neoseiulus baraki, however, showed no preference between infested and non-infested spikelets (Fig. 2). There were no significant differences among replicates $\left(\mathrm{G}_{\mathrm{H}}<5.83\right.$, d.f. $\left.=3, P>0.12\right)$.

Among the infested plant parts, the spikelets promoted greater attraction to both predators. Neoseiulus baraki preferred odours from infested fruits over leaflets of infested plants, but $P$. bickleyi preferred odours from leaflets of infested plants over infested fruits (Fig. 2). There were no significant differences among replicates $\left(\mathrm{G}_{\mathrm{H}}<1.29\right.$, d.f. $=3$, $P>0.73)$.

When given a choice between odours from infested aborted and non-aborted fruits, $P$. bickleyi preferred the aborted fruits $\left(\mathrm{G}_{\mathrm{P}}=20.92\right.$, d.f. $\left.=1, P<0.01\right)$ (Fig. 3). There were no significant differences among replicates $\left(\mathrm{G}_{\mathrm{H}}=0.53\right.$, d.f. $\left.=3, P=0.91\right)$.

\section{Arenas}

No significant differences were observed between the number of predators on each arm of the ' $\mathrm{T}$ ' in the blank test at any evaluation period, indicating the suitability of the experimental procedure $\left(\chi^{2}<0.15, P>0.69\right)$. Independent of the comparison, significantly more predators $(N$. baraki and $P$. bickleyi) were usually found on the epidermis discs of the coconut fruits infested with $A$. guerreronis at each evaluation period $\left(\chi^{2}>4.15, P<0.04\right)$. However, in some of the observations (30 min, 4 and $8 \mathrm{~h}$ ), P. bickleyi did not show preference between discs from infested fruits and pollen $\left(\chi^{2}<0.72, P>0.39\right)$. When 
(a)
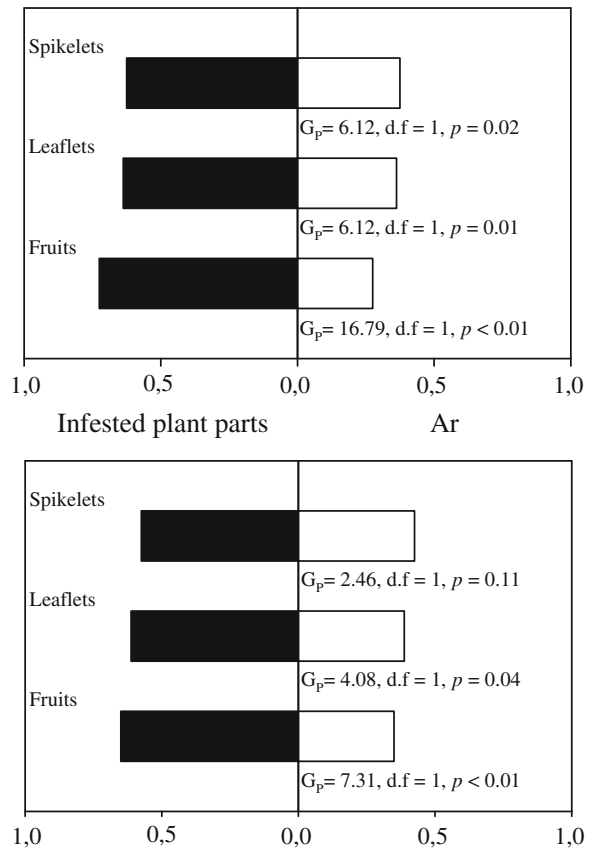

Infested plant parts $\quad$ Non-infested plant parts (b)
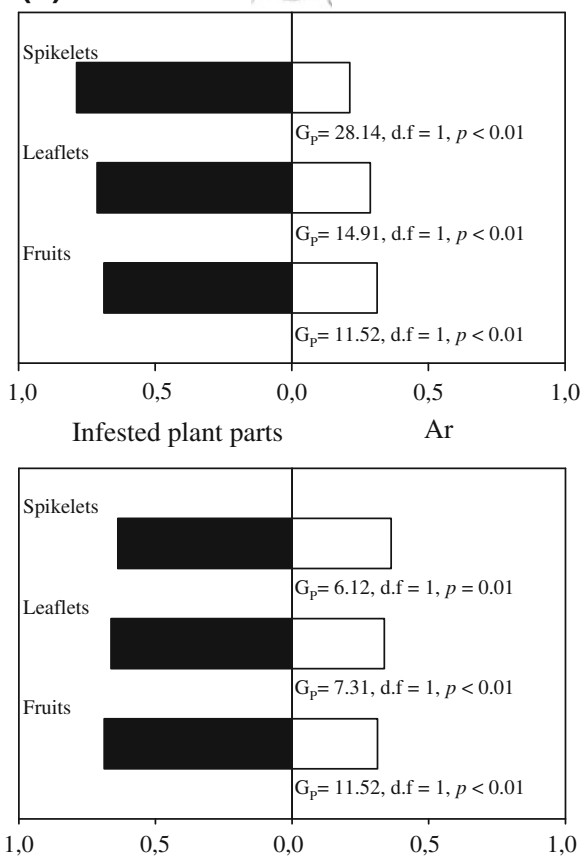
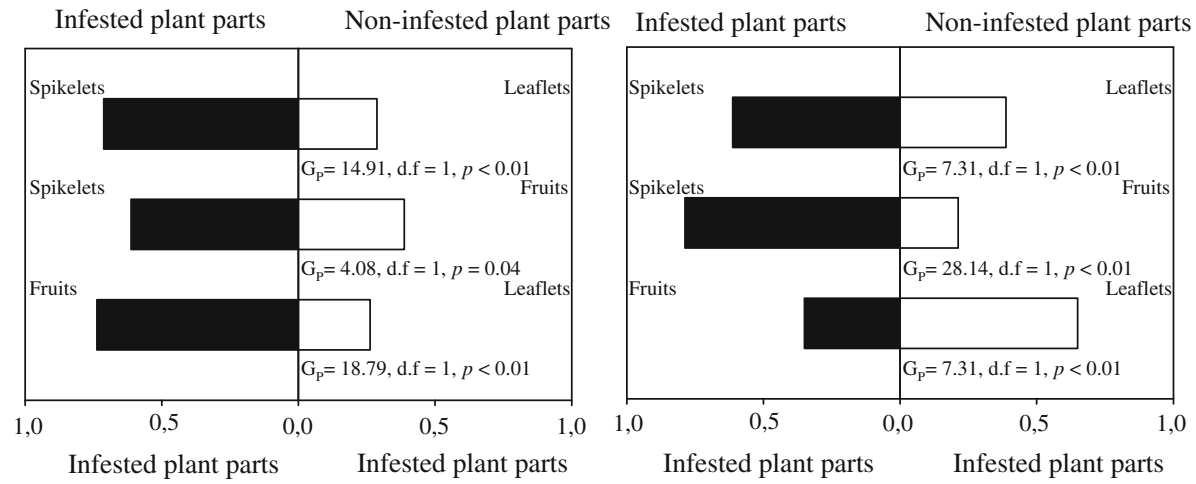

Fraction of predators

Fig. 2 Response of the predators Neoseiulus baraki (a) and Proctolaelaps bickleyi (b) to odours from parts of coconut plants infested or not by the eriophyid mite Aceria guerreronis and the air stream in a Y-tube olfactometer. Each bar shows the mean of four independent replicates (80 mites). Pooled results were tested with a replicated goodness-of-fit test

given a choice between coconut pollen versus epidermis discs of non-infested coconut fruits, $N$. baraki preferred epidermis discs of non-infested coconut fruits, but only up to $2 \mathrm{~h}$ after starting the experiment $\left(\chi^{2}>7.73, P<0.01\right)$. Conversely, $P$. bickleyi did not show a clear preference between epidermis discs of non-infested coconut fruits and pollen $\left(\chi^{2}>0.05, P<0.81\right)$ (Fig. 4). 
Fig. 3 Response of Proctolaelaps bickleyi to odours from aborted versus non-aborted coconut fruits infested by Aceria guerreronis in a Y-tube olfactometer. Each bar represents the result of one replicate, in which 20 mites were tested. Pooled results were tested with a replicated goodness-of-fit test

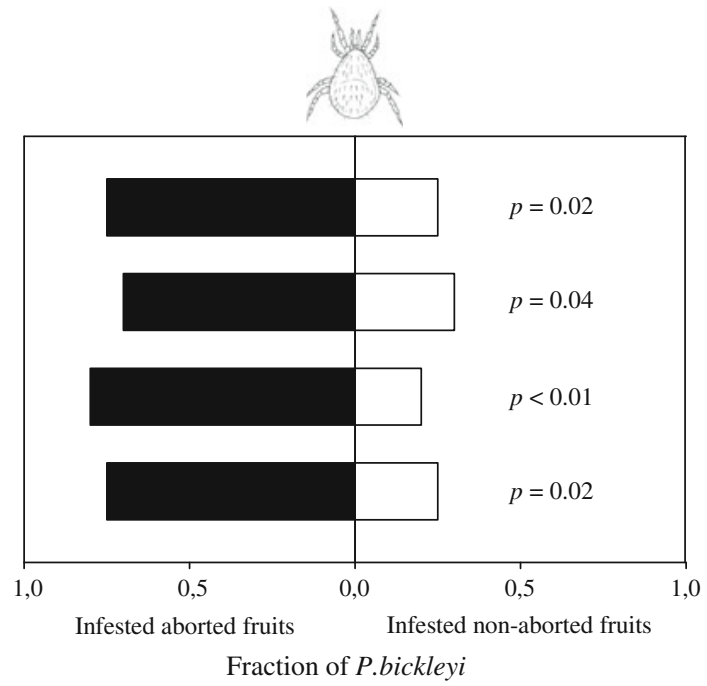

When we assessed the preference of $N$. baraki between epidermis discs of the infested coconut fruit and coconut pollen in the presence or absence of light, significantly more predators were found on epidermis discs of the infested coconut fruit $\left(\chi^{2}>29.48\right.$, $P<0.01)$ (Fig. 5).

\section{Discussion}

Neoseiulus baraki and P. bickelyi showed preference for infested plant parts (leaf, spikelet and fruit) over air stream. Possible explanations for these results are: (1) coconut plants under the attack of A. guerreronis have their defense system affected and might be systemically releasing volatiles in different parts of the plant (leaf, spikelets and fruits), which will be detected by the predators; (2) different sensory cues, such as those originated by the prey or the prey's by-products (eggs, faeces and exuviae), would be attracting the predators; (3) parts of coconut plants are attractive to predators independent of herbivore attack.

Sabelis and Dicke (1985) reported that the searching behavior of predatory mites follows a hierarchy of steps: (1) location of the habitat colonized by the prey, (2) location of the prey's colony within the habitat, and (3) location of individuals within the colony. Plants are able to signal various types of information through their aerial parts (Visser 1986; Sabelis and Dicke 1985; Turlings et al. 1990, 1995; Tumlinson et al. 1993; Sabelis et al. 1998, 2001; Dicke 1999; Arimura et al. 2005). Such information is of great importance for predators that use a variety of stimuli to locate the prey. Predators follow a sequence of responses to different sources of information, which leads them to forage closer to their prey continually (Price et al. 1980). This supports the first hypothesis (plants release the attracting cues). If the second hypothesis (predators respond to prey products) were true, only the fruits would be attractive to the predators, since the colony of A. guerreronis develops only in the fruits, which would not justify the attraction exerted by other parts (spikelets and leaflets). 
(a)

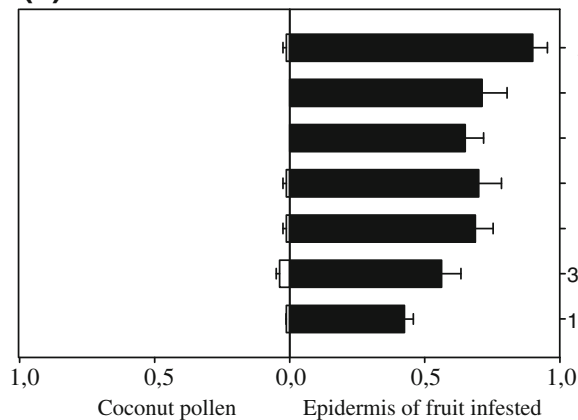

(b)
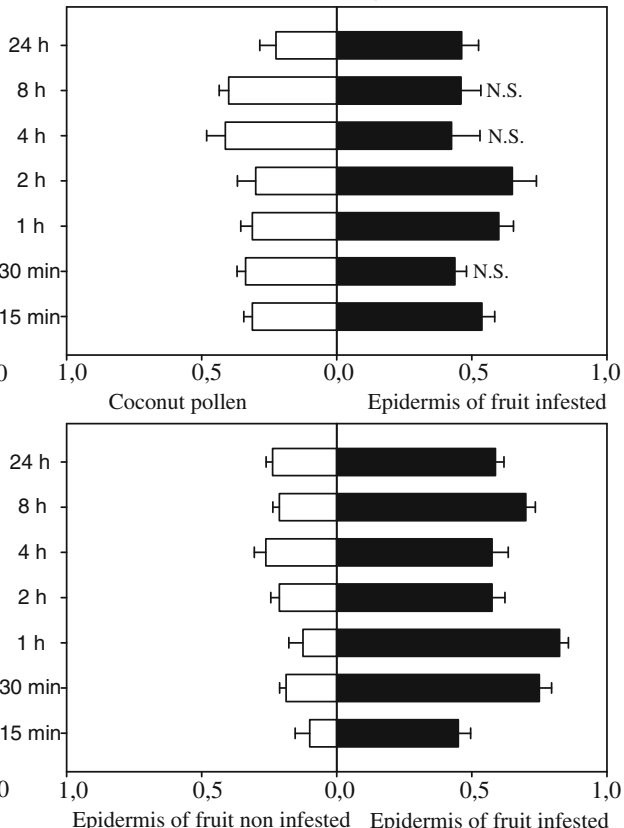

Epidermis of fruit non infested Epidermis of fruit infested

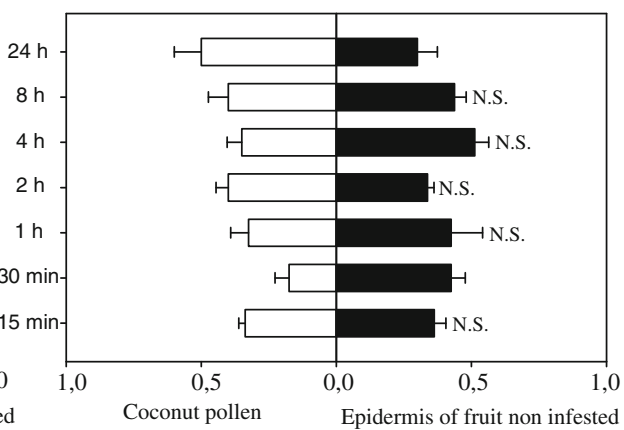

Fraction of predators

Fig. 4 Response of Neoseiulus baraki (a) and Proctolaelaps bickleyi (b) to odours from epidermis of fruit infested or not by the eriophyid mite Aceria guerreronis and the offering of coconut pollen in T-shaped arenas. Records scored at different periods after starting the tests. Differences between pairs are significant $\left(\chi^{2}\right.$ test, $\left.P<0.05\right)$, except when marked by N.S.

Neoseiulus baraki and P. bickleyi preferred, in the olfactometer, parts of plants infested by $A$. guerreronis (leaflets, spikelets or fruits) over non-infested parts, except for N. baraki offered odour from spikelets. However, it must be taken into account that these predators also feed on coconut pollen. In fact, $N$. baraki can fully develop solely on pollen (Domingos et al. 2010). This may explain, in part, why $N$. baraki did not show preference between infested and non-infested spikelets. The fact that both predators are able to distinguish between infested and non-infested parts of plants weakens the third hypothesis (coconut plant parts are just attractive). However, we cannot reject this hypothesis, because 


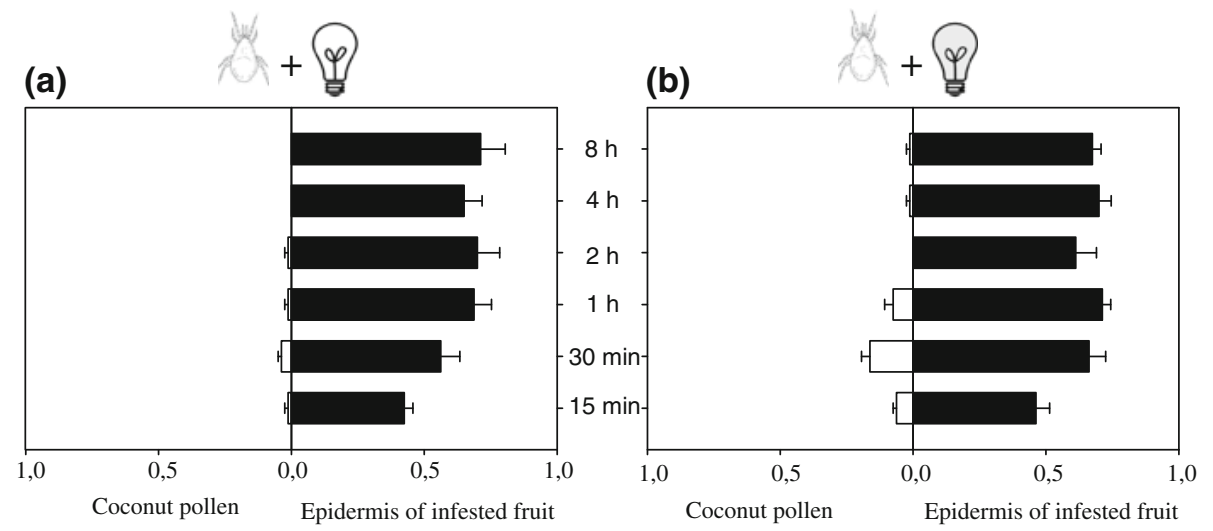

Fraction of predators

Fig. 5 Response of Neoseiulus baraki to odours from epidermis of coconut fruit infested by Aceria guerreronis versus coconut pollen in T-shaped arenas in the presence (a) and absence (b) of light. Records scored at different periods after starting the tests. Differences between pairs are significant in all cases $\left(\chi^{2}\right.$ test, $\left.P<0.05\right)$

perhaps the attractive plant parts are simply more attractive when attacked by A. guerreronis. Among the parts infested, the spikelets promoted a greater attractiveness to both predators. Some studies (Overmeer and van Zon 1983; Dicke et al. 1986) reported that predatory mites spend a large amount of energy both in the process of shifting to other infested plants, and on establishing a new population. This would require a supplement of vitamin A and carotenoids in their diet, which is found in the pollen grain. Therefore, the nutritional quality of food can also corroborate the fact that $N$. baraki does not differentiate the spikelets.

In additional comparison, it was observed that $P$. bickelyi prefer infested aborted fruits over infested non-aborted ones. Lawson-Balagbo et al. (2007b) reported that $P$. bickelyi is usually found on aborted fruits infested by A. guerreronis, and these fruits are often colonized by fungi of the genus Rhyzopus. Lima et al. (unpublished) observed that most of the $P$. bickelyi in association with fruit infested by A. guerreronis, were found in aborted fruits. Lawson-Balagbo et al. (2007b) found that among various diets tested for development and reproduction of $P$. bickelyi (mites, pollen and fungus from coconut), only Rhyzopus sp. and A. guerreronis were suitable food. These facts may partly explain why $P$. bickelyi prefer aborted over non-aborted fruits.

In the T-shaped arenas, at any comparison, a larger number of $N$. baraki and P. bickleyi were found at the end of the arms containing the epidermis discs of fruits infested with $A$. guerreronis. Predatory mites are known to use kairomones produced by the colonies of the phytophagous mites (webs, faeces and exuviae) and synomones released from the parts of infested plants as stimuli flags (Hislop and Prokopy 1981; Sabelis et al. 1984a, b; Sabelis and Dicke 1985; Dicke 1988; Dicke et al. 1993a, b; Takabayashi et al. 1994). Proctolaelaps bickleyi did not show a clear preference between epidermis discs of non-infested coconut fruits and pollen. Although coconut pollen allows the development and reproduction of $N$. baraki (Domingos et al. 2010), it is not suitable in the same way for P. bickleyi (Lawson-Balagbo et al. 2007b).

Discs of fruit epidermis infested by A. guerreronis were more attractive to both predators. However, it should be pointed out that the experiments were conducted most of the 
time in the presence of light $(15,30 \mathrm{~min}, 1,2,4$ and $8 \mathrm{~h})$. Thus, since $N$. baraki inhabits the perianth (an essentially dark environment), the results could have been influenced by the experimental set-up. As assessed by the present study, though, the day light did not seem to influence the foraging behavior of $N$. baraki.

The results showed here support that $N$. baraki and $P$. bickleyi can detect chemical cues emitted by coconut plants infested by A. guerreronis. Once on the infested coconut plant, the predators might seek for a more specific chemical cue related to the prey colony that would eventually lead them to their target—in line with Sabelis and Dicke's (1985) hypothesis that the location of a prey by predatory mites follows a hierarchy of steps.

This is the first study reporting evidence that the predators $N$. baraki and $P$. bickleyi may use volatile cues to locate their prey (A. guerreronis) on coconut plants. This ability can increase the efficiency of these predators by reducing the time required for prey localization, a desired foraging behavioral trait for biological control agents. The use of these predators may form a suitable alternative for small stakeholders, but also an extra strategy for larger growers that use integrated pest management approach, since chemical control is an expensive practice that requires periodic applications (Moore and Howard 1996; Ramaraju et al. 2002), besides the possible residues remaining on the coconut products. Additionally, the behavior of these predators should be further investigated under different field conditions, where other organisms and odours may be present.

Acknowledgments The National Council of Scientific and Technological Development (CNPq), the Pernambuco State Foundation for Research Aid (FACEPE) and the Coordination for the Improvement of Higher Education- Personnel (CAPES) are thanked for the financial support.

\section{References}

Arimura GI, Kost C, Boland W (2005) Herbivore-induced, indirect plant defences. Biochim Biophys Acta 1734:91-111

de Moraes GJ, Zacarias MS (2002) Use of predatory mites for the control of eriophyid mites. In: Fernando LCP, de Moraes GJ, Wickramananda IR (eds) Proceedings of the international workshop on coconut mite (Aceria guerreronis). Coconut Research Institute, Sri Lanka, pp 79-88

Dicke M (1988) Prey preference of the phytoseiid mite Typhlodromus pyri 1-Response to volatile kairomones. Exp Appl Acarol 4:1-13

Dicke M (1994) Local and systemic production of volatile herbivore-induced terpenoids: their role in plantcarnivore mutualism. J Plant Physiol 143:465-472

Dicke M (1999) Evolution of induced indirect defense of plants. In: Tollrian R, Harvell CD (eds) The ecology and evolution of inducible defenses. Princeton University Press, Princeton, pp 62-88

Dicke M, Sabelis MW (1988) How plants obtain predatory mites as bodyguards. Neth J Zool 38:148-165

Dicke M, Sabelis MW, Groeneveld A (1986) Vitamin A deficiency modifies response of the predatory mite Amblyseius potentillae to volatile kairomone of twospotted mite, Tetranychus urticae. J Chem Ecol 12:1389-1396

Dicke M, van Baarlen P, Wessels R, Dijkman H (1993a) Herbivory induces systemic production of plant volatiles that attract predators of the herbivore: extraction of endogenous elicitor. J Chem Ecol 19:581-599

Dicke M, van Baarlen P, Wessels R, Dijkman H (1993b) Systemic production of herbivore-induced synomones by lima bean plants helps solving a foraging problem of the herbivore's predators. Proc Exp Appl Entomol 4:39-44

Dicke M, Takabayashi J, Posthumus MA, Schüte C, Krips OE (1998) Plant-phytoseiid interactions mediated by herbivoreinduced plant volatiles: variation in production of cues and in responses of predatory mites. Exp Appl Acarol 22:311-333

Dicke M, De Boer JG, Höfte M, Rocha-Granados MC (2003) Mixed blends of herbivore-induced plant volatiles and foraging success of carnivorous arthropods. Oikos 101:38-48 
Domingos CA, Melo JWS, Gondim MGC Jr, de Moraes GJ, Rachid H, Lawson-Balagbo LM, Peter S (2010) Diet-dependent life history, feeding preference and thermal requirements of the predatory mite Neoseiulus baraki (Acari: Phytoseiidae). Exp Appl Acarol 50:201-215

Doreste SE (1968) El ácaro de la flor del cocotero (Aceria guerreronis Keifer) en Venezuela. Agron Trop 18:370-386

Fernando LCP, Wickramananda IR, Aratchige NS (2002) Status of coconut mite, Aceria guerreronis in Sri Lanka. In: Fernando LCP, Moraes GJ, Wickramananda IR (eds) Proceedings of the International Workshop on Coconut Mite (Aceria guerreronis). Coconut Research Institute, Sri Lanka, pp 1-8

Fernando LCP, Waidyarathne KP, Perera KFG, De Silva PHPR (2010) Evidence for suppressing coconut mite, Aceria guerreronis by inundative release of the predatory mite, Neoseiulus baraki. Biol Control 53:108-111

Galvão AS, Gondim MGC Jr, Michereff SJ (2008) Escala diagramática de Dano de Aceria guerreronis Keifer (Acari: Eriophyidae) em coqueiro. Neotrop Entomol 37:723-728

Haq MA, Sumangala K, Ramani N (2002) Coconut mite invasion, injury and distribution. In: Fernando LCP, Moraes GJ, Wickramananda IR (eds) Proceedings of the international workshop on coconut mite (Aceria guerreronis). Coconut Research Institute, Sri Lanka, pp 41-49

Hislop RG, Prokopy RJ (1981) Mite predator responses to prey and predator-emitted stimuli. J Chem Ecol 7:895-904

Hurlbert SH (1984) Pseudoreplication and the design of ecological field experiments. Ecol Monogr 54:187-211

Jagers op Akkerhuis G, Sabelis MW, Tjallingii WF (1985) Ultrastructure of chemoreceptors on the pedipalpis and first tarsi of Phytoseiulus persimilis. Exp Appl Acarol 1:235-251

Janssen A, Bruin J, Jacobs G, Schraag R, Sabelis MW (1997) Predators use odours to avoid prey patches with conspecifics. J Anim Ecol 66:223-232

Janssen A, Pallini A, Venzon M, Sabelis MW (1999) Absence of odour-mediated avoidance of heterospecific competitors by the predatory mite Phytoseiulus persimilis. Entomol Exp Appl 92:73-82

Kumar PS, Singh SP (2000) Hirsutella thompsonii. The best biological control option for the management of the coconut mite in India. Indian Coconut J 31:11-15

Lawson-Balagbo LM, Gondim MGC Jr, Moraes GJ, Hanna R, Schausberger P (2007a) Life history of the predatory mites Neoseiulus paspalivorus and Proctolaelaps bickleyi, candidates for biological control of Aceria guerreronis. Exp Appl Acarol 43:49-61

Lawson-Balagbo LM, Gondim MGC Jr, Moraes GJ, Hanna R, Schausberger P (2007b) Refuge use by the coconut mite Aceria guerreronis: fine scale distribution and association with other mites under the perianth. Biol Control 43:102-110

Lawson-Balagbo LM, Gondim MGC Jr, Moraes GJ, Hanna R, Schausberger P (2008a) Exploration of the acarine fauna on coconut palm in Brazil with emphasis on Aceria guerreronis (Acari: Eriophyidae) and its natural enemies. Bull Entomol Res 98:83-96

Lawson-Balagbo LM, Gondim MGC Jr, Moraes GJ, Hanna R, Schausberger P (2008b) Compatibility of Neoseiulus paspalivorus and Proctolaelaps bickleyi, candidate biocontrol agents of the coconut mite Aceria guerreronis: spatial niche use and intraguid predation. Exp Appl Acarol 45:1-13

Maeda T, Tabayashi J (2001) Production of herbivore-induced plant volatiles and their attractiveness to Phytoseiulus persimilis (Acari: Phytoseiidae) with changes of Tetranychus urticae (Acari: Tetranychidae) density on plant. Appl Entomol Zool 36:47-52

Maeda T, Tabayashi J, Yano S, Takafuji A (2000) The effects of rearing coditions on the laboratory response of predatory mites, Phytoseiulus persimilis and Amblyseius womersleyi (Acari: Phytoseiidae). Appl Entomol Zool 35:345-351

Moore D, Howard FW (1996) Coconuts. In: Lindquist EE, Sabelis MW, Bruin J (eds) Eriophyoid mites: their biology natural enemies and control. Elsevier, Amsterdam, pp 561-570

Navia D, Moraes GJ, de Querino RB (2006) Geographic variation in the coconut mite, Aceria guerreronis Keifer (Acari: Eriophyidae): a geometric morphometric analysis. Int J Acarol 32:301-314

Oliveira H, Fadini M, Venzon M, Rezende D, Rezende F, Pallini A (2009) Evaluation of the predatory mite Phytoseiulus macropilis (Acari: Phytoseiidae) as a biological control agent of the two-spotted spider mite on strawberry plants under greenhouse conditions. Exp Appl Acarol 47:275-283

Overmeer WPJ, Van Zon AQ (1983) The effect of different kinds of food on induction of diapause in the predaceous mite Amblyseius potentillae. Entomol Exp Appl 33:27-30

Passos EEM (1994) Ecofisiologia do coqueiro. In: Ferreira JMS, Warwick DRN, Siqueira LA (eds) A cultura do coqueiro no Brasil. EMBRAPA-SPI, Aracaju, pp 74-86

Persley GJ (1992) Replanting the tree of life: towards an international agenda for coconut palm research. CAB, Wallingford, p 156 
Price PW, Bouton CE, McPheron BA, Thompson JN, Weis AE (1980) Interaction among three levels: influence of plants on interactions between insects herbivores and natural enemies. Annu Rev Ecol Syst $11: 41-65$

Ramaraju K, Natarajan K, Babu PCS, Palnisamy S, Rabindra RJ (2002) Studies on coconut eriophyid mite, Aceria guerreronis Keifer in Tamil Nadu, Índia. In: Fernando LCP, de Moraes GJ, Wickramananda IR (eds) Proceedings of the international workshop on coconut mite (Aceria guerreronis). Coconut Research Institute, Sri Lanka, pp 13-31

Reis AC, Gondim MGC Jr, de Moraes GJ, Hanna R, Schausberger P, Lawson-Balagbo LM, Barros R (2008) Population dynamics of Aceria guerreronis Keifer (Acari: Eriophyidae) and associated predators on coconut fruits in northeastern Brazil. Neotrop Entomol 37:457-462

Sabelis MW, Dicke M (1985) Long-range dispersal and searching behaviour. In: Helle W, Sabelis MW (eds) Spider mites: their biology natural enemies and control. Elsevier, Amsterdam, pp 141-160

Sabelis MW, Janssen A (1993) Evolution of life-history patterns in the Phytoseiidae. In: Wrensch DL, Ebberts MA (eds) Evolution and diversity of sex ratio in insects and mites. Chapman and Hall, New York, pp 70-99

Sabelis MW, van de Baan HE (1983) Location of distant spider mite colonies by phytoseiid predators: demonstration of specific kairomones emitted by Tetranychus urticae and Panonychus ulmi. Entomol Exp Appl 33:303-314

Sabelis MW, Afman BP, Slim PJ (1984a) Location of distant spider mite colonies by Phytoseiulus persimilis: localization and extraction of a kairomone. In: Griffith DA, Bowman CB (eds) Proceedings of the 6th International Congress of Acarology Chichester, Ellis Horwood, pp 431-440

Sabelis MW, Vermaat JE, Groeneveld A (1984b) Arrestment responses of the predatory mite, Phytoseiulus persimilis, to steep odour gradients of a kairomone. Physiol Entomol 9:437-446

Sabelis MW, van Baalen M, Bakker FM, Bruin J, Drukker B, Egas M, Janssen ARM, Lesna IK, Pels B, Van Rijn P, Scutareanu P (1998) The evolution of direct and indirect plant defence against herbivorous arthropods. In: Olff H, Brown VK, Drent RH (eds) Herbivores: between plants and predators. Oxford, Blackwell Science, pp 109-166

Sabelis MW, Janssen A, Kant MR (2001) The enemy of my enemy is my ally. Science 291:2104-2105

SAS Institute (1999-2001) SAS/STAT User's guide, version 8.02, TS level 2MO. SAS Institute Inc., Cary, $\mathrm{NC}$

Sokal RR, Rohlf FJ (1995) Biometry: the principles and practice of statistics in biological research. Freeman, New York, p 880

Takabayashi J, Dicke M, Takahashi S, Posthumus MA, van Beek TA (1994) Leaf age affects composition of herbivore-induced synomones and attraction of predatory mites. J Chem Ecol 20:373-386

Tumlinson JH, Turlings TCJ, Lewis WJ (1993) Semio-chemically mediated foraging behavior in beneficial parasitic insects. Arch Insect Biochem Physiol 22:385-391

Turlings TCJ, Tumlinson JH, Lewis WJ (1990) Exploitation of herbivore-induced plant odors by hostseeking parasitic wasps. Science 250:1251-1253

Turlings TCJ, Loughrin JH, McCall PJ, Rose U, Lewis WJ, Tumlinson JH (1995) How caterpillar-damaged plants protect themselves by attracting parasitic wasps. Proc Natl Acad Sci USA 92:4169-4174

Van Zandt PA, Agrawal AA (2004) Specificity of induced plant responses to specialist herbivores of the common milkweed Asclepias syriaca. Oikos 104:401-409

Visser JH (1986) Host odour perception in phytophagus insects. Annu Rev Entomol 31:121-144 